\title{
Antioxidant effects of black garlic powder on spent duck meat nugget quality during storage
}

\author{
Tiara Uji LISHIANAWATI ${ }^{1}$ (D), Lies Mira YUSIATI ${ }^{1}$ (D), JAMHARI ${ }^{1^{*}}$
}

\begin{abstract}
The effect of black garlic powder on the quality of spent duck meat nuggets during storage was investigated. This study used a completely randomized design with $4 \times 4$ factorial. The first factor was black garlic powder $(0 \%, 1 \%, 2 \%)$ and $200 \mathrm{ppm}$ Butylated hydroxytoluene then the second factor was the storage period $(0,10,20$, and 30 days) in refrigerator temperature. Physical quality, chemical quality, antioxidant activity, and total plate count (TPC) data were collected and analyzed using analysis of variance. Sensory quality data were collected and analyzed using the Kruskal-Wallis test. The results showed that the addition of $2 \%$ black garlic powder significantly increased $(\mathrm{P}<0.01)$ the color redness $\left(\mathrm{a}^{*}\right)$, total phenol, and 2,2-diphenyl-1-picrylhydrazyl $(\mathrm{DPPH})$ inhibition. However, it decreased $(\mathrm{P}<0.05)$ the $\mathrm{pH}$, lightness $\left(\mathrm{L}^{*}\right)$, peroxide value, TPC, color, aroma, and acceptability. Storage time increased $(\mathrm{P}<0.05)$ was decreased the $\mathrm{pH}, \mathrm{L}^{*}, \mathrm{a}^{\star}$, tenderness, protein, total phenol, and DPPH inhibition but increased $(\mathrm{P}<0.01)$ the yellowness $\left(\mathrm{b}^{*}\right)$, peroxide value, and TPC. The addition of $1 \%$ black garlic powder was recommended to increase the spent duck meat nugget quality during storage without decreased the sensory quality of nuggets.
\end{abstract}

Keywords: antioxidant activity; black garlic powder; nugget quality; spent duck meat; storage period.

Practical Application: Black garlic powder prevents oxidation on spent duck meat nuggets during storage.

\section{Introduction}

Spent ducks are female ducks that are no longer productive and have an average age of more than two years. Spent duck meat characteristic is tough, dark in color, pungent odor, high fat (3.84-8.47\%), and high protein content 16.96-20.4\% (Damayanti, 2006; Ali et al., 2007; Matitaputty \& Suryana, 2010). Duck meat contains high unsaturated fatty acids and low saturated fatty acids compared to chicken meat. About $60 \%$ of total fatty acids are unsaturated fatty acids (Ali et al., 2007; Shin et al., 2019). Based on its meat's toughness, duck meat needs to be processed into a product like nuggets.

Nugget is one of restructured breaded product that widely accepted by consumers (Schuch et al., 2019). The processing and storage period of nuggets that are directly exposed to heat, air, or light could initiate oxidation (Amaral et al., 2018). The relatively high-fat content, especially unsaturated fatty acid, also facilitates the oxidation process that produces free radicals. Oxidative change can cause rancidity that affects its flavors, loss of color, and altered nutrient value (Ahmed et al., 2016; Papuc et al., 2017a; Domínguez et al., 2019). One method to prevent oxidation in meat and meat products is by adding an antioxidant to maintaining meat product quality and extending shelf-life. Antioxidants that are often used are Butylated hydroxyanisole (BHA) and Butylated hydroxytoluene (BHT). Both of these synthetic antioxidants can generate health disease and carcinogenic if consumed frequently. Thus, alternative antioxidants derived from natural ingredients are needed to reduce the problem. Black garlic can be used as a natural antioxidant without a high impact on health problems.
Black garlic is processed garlic under high temperature $\left(65-90^{\circ} \mathrm{C}\right)$ and humidity (60-80\%) during a period (Kimura et al., 2017; Lu et al., 2017). Black garlic has a brown color, less flavor, and high antioxidant properties. Total phenolic of black garlic increases 4-10 fold compared to fresh garlic. Total polyphenol, flavonoid, and antioxidant activity were $58.33 \mathrm{mg} \mathrm{GAE} / \mathrm{g}, 15.37 \mathrm{mg} \mathrm{RE} / \mathrm{g}$, and $74.48 \%$, respectively (Choi et al., 2014). Not only as antioxidant agents, black garlic also act as antimicrobials (Altuntas \& Korukluoglu, 2019). Black garlic contain phenolic compound, $\beta$-carbolines alkaloids (Cao et al., 2007), melanoidins (Wang et al., 2011), organic acids and organic sulfur compound (Yin \& Cheng, 2003; Lin et al., 2019). According to Arslaner (2020) organic sulfur compound decrease the yeast-mould compared to the control. This study aimed to determine the antioxidant effect of black garlic powder as a source of natural antioxidants on the physical quality, chemical quality, antioxidant activity, TPC, and sensory quality, of duck nuggets during storage.

\section{Materials and methods}

\subsection{Raw materials}

Duck meat procured from the local market in Bantul, Yogyakarta, Indonesia, was packed in clean polyethylene bags and quickly brought to the Meat Science and Technology Laboratory of Department of Animal Products Technology, Universitas Gadjah Mada, Indonesia. Additives materials used were starch flour, skim milk, salt, sugar, pepper, garlic, and ice. The formulation of duck nuggets is given in Table 1. Fresh garlic was purchased from the local market and processed under 
Table 1. Duck nugget formulation.

\begin{tabular}{ccc}
\hline No. & Ingredient & Percentage (\%) \\
\hline 1. & Duck meat & 70 \\
2. & Starch flour & 10 \\
3. & Skim milk & 10 \\
4. & Salt & 2 \\
5. & Sugar & 2 \\
6. & Pepper & 1 \\
7. & Garlic & 1 \\
8. & Ice & 4 \\
& Total & 100 \\
\hline
\end{tabular}

temperature $70{ }^{\circ} \mathrm{C}$ and humidity $80 \%$ for 14 days (Choi et al., 2014). Peeled black garlic was dried after fine chopping in a $50{ }^{\circ} \mathrm{C}$ oven and then ground to the powder (Wang \& Sun, 2017). Black garlic powder was kept chilled until it was added to the duck nugget formulation.

\subsection{Experimental design}

This study's experimental design was a completely randomized design with $4 \mathrm{x} 4$ factorial. The first factor was the level of black garlic powder $(0 \%, 1 \%, 2 \%)$ and BHT $200 \mathrm{ppm}$ then the second factor was the storage period $(0,10,20$, and 30 days).

\subsection{Preparation of nuggets}

Duck breast, thigh, and skin were chopped. In the pre-weighed quantity of minced goat meat, salt was added and chop for 2-3 min with simultaneous addition of ice flakes. Garlic, pepper, sugar, skim milk, and starch was added after chopping was completely dispersed. Black garlic powder was added based on the weight of the emulsion. Chopping continued till uniform dispersion of all ingredients and desired consistency of the emulsion was achieved. The emulsion was filled in stainless steel and cooked at $85^{\circ} \mathrm{C}$ for $35 \mathrm{~min}$ (Banerjee et al., 2012). Duck meat blocks were sliced and cut into pieces to get nuggets $(4 \times 3 \times 1.5 \mathrm{~cm})$ and were chilled for $30 \mathrm{~min}$. The pieces of nugget were dipped in the white egg and then breaded. The products were aerobically packaged in polyethylene bags and stored at $4{ }^{\circ} \mathrm{C}$ for 30 days.

\subsection{Product analysis}

pH value

A total of $2 \mathrm{~g}$ of the nugget was added with $18 \mathrm{~mL}$ distilled water and homogenized. The $\mathrm{pH}$ was recorded using a digital pH meter (Hanna Checker $1 \mathrm{pH}$ Taster, Hanna Instruments, Ann Arbor, Michigan, USA). The $\mathrm{pH}$ meter was calibrated with standard buffers before use as per the manufacturer's instructions (Korkeala et al., 1986).

\section{Instrumental colour value}

The instrumental color on the nuggets is analyzed using the Chromameter Konica Minolta CR-400 to determine lightness $\left(\mathrm{L}^{*}\right)$, redness $\left(\mathrm{a}^{*}\right)$, and yellowness $\left(\mathrm{b}^{*}\right)$ (Konica Minolta, 2013).

\section{Tenderness}

Tenderness of nugget was determined using penetrometer according to the method of Hinnergardt \& Tuomy (1970). A $1.5 \mathrm{~cm}$ thick nugget was placed under the penetrometer machine's needle with a weight of $50 \mathrm{~g}$, and its chuck was released for $10 \mathrm{~s}$. The length of penetration of the chuck into the sample $(\mathrm{mm})$ was recorded.

\section{Proximate composition}

The moisture, protein, fat, and ash content of fresh garlic, black garlic powder, and spent duck meat nugget were determined by the method of Association of Official Analytical Chemists (2005).

\section{Total Phenol}

Two hundred milligrams of ground nugget samples were mixed with $10 \mathrm{~mL}$ acetone $70 \%$ and extracted with ultrasonic extraction for $20 \mathrm{~min}(2 \times 10 \mathrm{~min}, 5 \mathrm{~min}$ rest in between $)$ at room temperature. The extract was centrifuged for $10 \mathrm{~min}$ at $3000 \mathrm{rpm}$. One milliliter of supernatant was combined with $0.5 \mathrm{~mL}$ Folin-Ciocalteu $1 \mathrm{~N}$ and $2.5 \mathrm{~mL}$ a sodium carbonate $20 \%$, vortexed, and then held for $40 \mathrm{~min}$ at room temperature. The absorbance was measured at $725 \mathrm{~nm}$. A standard curve was plotted using different gallic acid concentrations, and the amount of total phenol was calculated as gallic acid equivalents (GAE) in mg/g (Singleton et al., 1999).

\section{DPPH inhibition}

DPPH inhibition was measured using the method of Shimamura et al. (2014). Two hundred milliliters sample extract was mixed with $1 \mathrm{~mL}$ DPPH $0.2 \mathrm{mM}$ and $800 \mu \mathrm{L} 0.1 \mathrm{M}$ Tris$\mathrm{HCl}$ buffer, and the mixture was vortexed. The tubes were then incubated at room temperature for $30 \mathrm{~min}$ in the dark, and the absorbance was taken at $517 \mathrm{~nm}$. For blank control, $200 \mathrm{~mL}$ distilled water ware used.

\section{Peroxide value}

Peroxide value was determined according to Shantha \& Decker (1994). Three hundred milligrams sample was mixed with $9.8 \mathrm{~mL}$ chloroform-methanol (7:3 v/v) and vortexed. Ammonium thiocyanate solution $(50 \mu \mathrm{L})$ and the sample was mixed on vortex. Then, $50 \mu \mathrm{L}$ iron (II) chloride solution was added and vortexed. After a 5 min incubation at room temperature, the absorbance was determined at $500 \mathrm{~nm}$. The blank control contained all the reagents except the sample. A standard curve was plotted using different iron (III) chloride concentrations, and the peroxide value was calculated as milliequivalents (Meq) peroxide $/ \mathrm{kg}$.

\section{Total plate count}

At the specified sample time, nuggets were aseptically removed from the bag. Twenty-five grams of sample was placed in a sterile bag containing $225 \mathrm{~mL}$ of sterile saline solution (0.85\%) and homogenized. Serial dilutions were then made. Standard plate count was determined on Plate count agar (PCA) using the pour plate method incubated at $37 \pm 2{ }^{\circ} \mathrm{C}$ for $48 \mathrm{~h}$. The microbial 
counts were expressed as $\log _{10}$ colony-forming units (CFU) per gram of sample (Badan Standardisasi Nasional, 2008).

\section{Sensory evaluation}

For the sensory evaluation test, the duck nugget was fried in cooking oil until golden brown and served to panelists. Sensory evaluation was conducted by 20 panelists of both gender, aged from 20-40 years old. The panelists are undergraduate and graduate students in the Faculty of Animal Science, Universitas Gadjah Mada, Indonesia. The sensory attributes such as color, aroma, taste, texture, and overall acceptability of each sample were evaluated using 5 points hedonic scale (Costa et al., 2020); five denoted extremely like and one denoted extremely dislike. The panelists were informed about the nature of the experiment without disclosing the identity of the samples. Water was served to cleanse the mouth between samples (Nascimento et al., 2020).

\subsection{Statistical analysis}

Physical quality, chemical quality, antioxidant activity, and TPC data were analyzed using variance analysis followed by Duncan's New Multiple Ranges Test (DMRT) to separate among means with significance level at $\mathrm{P}<0.05$. The sensory quality was analyzed using the non-parametric Kruskal Wallis followed by the Mann-Whitney test using the SPSS Statistic 16.0 program.

\section{Results and discussion}

\subsection{Black garlic powder}

Proximate composition and $\mathrm{pH}$

Proximate analysis of fresh garlic and black garlic powder is presented in Table 2. The nutrient content of black garlic powder was varies depending on the manufacturing process. The moisture, protein, fat, and ash content of black garlic powder according to Lee et al. (2009) were 9,$11 ; 7,12 ; 0.02$, and $1.82 \%$, while according to Berliana et al. (2018), were $31.94 ; 15.66 ; 3.57$, and $4.03 \%$. The $\mathrm{pH}$ value decreased during processing, which agrees with the finding of Choi et al. (2008), who reported that the $\mathrm{pH}$ of fresh garlic was 6.84 and decreased to 4.36 after processed.

\section{Total phenolic and DPPH inhibition}

Phenolic compounds are the major group of acting as primary antioxidant or free radical terminators. Phenolic compounds can act as hydrogen or electron donors. An increase

Table 2. Properties of fresh garlic and black garlic powder.

\begin{tabular}{lccc}
\hline \multicolumn{1}{c}{ Parameters } & Fresh garlic & $\begin{array}{c}\text { Black garlic } \\
\text { powder }\end{array}$ & BHT \\
\hline Moisture (\%) & 67.06 & 16.94 & - \\
Protein (\%) & 0.89 & 15.76 & - \\
Fat (\%) & 0.32 & 2.26 & - \\
Ash (\%) & 0.86 & 14.82 & - \\
pH & 6.26 & 4.47 & - \\
Total phenol (mg & 12.08 & 62.70 & - \\
GAE/g) & & 80.91 & 84.30 \\
DPPH (\%) & 48.15 & & \\
\hline
\end{tabular}

in the phenolic compound will increase the DPPH inhibition. Black garlic powder rich in a phenolic compound and higher DPPH inhibition compared to fresh garlic. Choi et al. (2014) reported that the total black garlic polyphenols increased from $13.91 \mathrm{mg} \mathrm{GAE} / \mathrm{g}$ to $58.33 \mathrm{mg} \mathrm{GAE} / \mathrm{g}$ and DPPH inhibition from $4.65 \%$ to $74.48 \%$.

\subsection{Physical properties of nugget}

pH value

The nugget's $\mathrm{pH}$ was significantly decreased by black garlic powder and storage period (Table 3 ). The $\mathrm{pH}$ values of nuggets with black garlic powder were significantly lower than control and BHT. It could be attributed to the added black garlic powder, which has a low pH of 4.47 (Table 2). The addition of BHT did not affect the $\mathrm{pH}$ value of the nuggets. As the storage period, the $\mathrm{pH}$ value of the nuggets was decreased gradually. The decreasing $\mathrm{pH}$ value was probably due to the lactic acid bacteria (LAB) activity (Cayré et al., 2003). There was an increase in LAB amount during the ground beef storage period (Sallam \& Samejima, 2004). The current result is also in agreement with the finding of Rahman et al. (2020), who showed that $0.3 \%$ of Moringa leaf extract increased the $\mathrm{pH}$ of goat nuggets and decreased during 45 days of storage. Kumar et al. (2015) also reported a similar finding that pork patty with $0.3 \%$ sea buckthorn and $0.1 \%$ grape extract reduced the $\mathrm{pH}$ during 21 days of storage.

\section{Instrument colour parameter}

Konica Minolta color values of nuggets during storage were showed in Table 3. Incorporation of black garlic powder significantly decreases the $L^{*}$, increases the $a^{\star}$, and did not affect the $b^{*}$ value. The addition of BHT does not affect $L^{*}, a^{*}$, and $\mathrm{b}^{*}$ values. The decrease in the $\mathrm{L}^{\star}$ and the increase $\mathrm{a}^{*}$ was caused by the dark-brown black garlic powder, which affected the duck nuggets' color. Kim et al. (2019) also reported that the addition of $2 \%$ aged garlic powder was decreased color instrument $L^{*}$ and increase $\mathrm{a}^{*}$ and $\mathrm{b}^{*}$ value. Storage period decrease $\mathrm{L}^{*}, \mathrm{a}^{*}$ and increase $\mathrm{b}^{*}$ value. Meat and meat products will be darkened if stored for a certain period, thereby reducing the $\mathrm{L}^{*}$ value (Shin et al., 2011). Decreasing the $\mathrm{a}^{*}$ and increasing $\mathrm{b}^{*}$ value indicates a reduction in the red color of the nugget. It is caused by the oxidation of myoglobin, which accumulates to metmyoglobin during storage (Sánchez-Escalante et al., 2001; Gahruie et al., 2017). Lara et al. (2011) reported that pork patty was given an additional $0.03 \%$ rosemary extract and $0.1 \%$ lemon balm decreased $L^{*}$, increased $\mathrm{a}^{*}$, and did not affect $\mathrm{b}^{*}$ value but during storage decreased the $a^{*}$ value. Kumar et al. (2015) also reported that the use of $0.3 \%$ sea buckthorn and $0.1 \%$ grape extract decreased $L^{*}$, increased $\mathrm{a}^{*}$, and did not affect $\mathrm{b}^{*}$ pork patty during 21 days of storage decreased $L^{*}, a^{*}$ and did not affect $b^{*}$ value.

\section{Tenderness}

The addition of black garlic powder and BHT did not affect the tenderness of the nugget. It is due to the added small amount of black garlic powder and BHT, namely $2 \%$ and $200 \mathrm{ppm}$. According to Lukman et al. (2009) and Santhi et al. (2017) tenderness of processed meat products is more influenced by the type of protein, 
Table 3. Effect of black garlic powder and BHT on physical properties of duck nugget during storage.

\begin{tabular}{|c|c|c|c|c|c|c|}
\hline \multirow{2}{*}{ Physical properties } & \multirow{2}{*}{ Storage period } & \multicolumn{3}{|c|}{ Black garlic powder (\%) } & \multirow{2}{*}{$\frac{\text { BHT }}{200 \mathrm{ppm}}$} & \multirow[t]{2}{*}{ Average } \\
\hline & & 0 & 1 & 2 & & \\
\hline \multirow[t]{5}{*}{$\mathrm{pH}$} & 0 & $6.50 \pm 0.01$ & $6.41 \pm 0.03$ & $6.34 \pm 0.02$ & $6.50 \pm 0.06$ & $6.44 \pm 0.07^{\mathrm{d}}$ \\
\hline & 10 & $6.44 \pm 0.04$ & $6.38 \pm 0.01$ & $6.32 \pm 0.01$ & $6.47 \pm 0.02$ & $6.40 \pm 0.06^{c}$ \\
\hline & 20 & $6.41 \pm 0.03$ & $6.35 \pm 0.02$ & $6.28 \pm 0.01$ & $6.44 \pm 0.03$ & $6.37 \pm 0.07^{\mathrm{b}}$ \\
\hline & 30 & $6.38 \pm 0.02$ & $6.34 \pm 0.02$ & $6.27 \pm 0.02$ & $6.39 \pm 0.02$ & $6.35 \pm 0.05^{\mathrm{a}}$ \\
\hline & Average & $6.44 \pm 0.05^{c}$ & $6.37 \pm 0.03^{b}$ & $6.30 \pm 0.03^{a}$ & $6.45 \pm 0.05^{c}$ & \\
\hline \multirow[t]{5}{*}{ Lightness } & 0 & $50.06 \pm 2.77$ & $42.07 \pm 0.92$ & $37.77 \pm 0.64$ & $49.51 \pm 1.22$ & $44.85 \pm 5.57^{\mathrm{b}}$ \\
\hline & 10 & $49.31 \pm 2.07$ & $41.69 \pm 1.55$ & $37.02 \pm 2.30$ & $48.30 \pm 1.78$ & $44.08 \pm 5.50^{\mathrm{ab}}$ \\
\hline & 20 & $48.71 \pm 1.59$ & $40.75 \pm 1.50$ & $36.91 \pm 0.13$ & $47.98 \pm 1.67$ & $43.59 \pm 5.30^{\mathrm{ab}}$ \\
\hline & 30 & $46.84 \pm 0.58$ & $40.54 \pm 1.15$ & $36.79 \pm 0.46$ & $47.75 \pm 0.88$ & $42.98 \pm 4.78^{a}$ \\
\hline & Average & $48.73 \pm 2.06^{c}$ & $41.26 \pm 1.30^{\mathrm{b}}$ & $37.12 \pm 1.11^{\mathrm{a}}$ & $48.39 \pm 1.41^{c}$ & \\
\hline \multirow[t]{5}{*}{ Redness } & 0 & $5.57 \pm 0.76$ & $5.94 \pm 0.39$ & $6.47 \pm 0.36$ & $5.40 \pm 0.44$ & $5.84 \pm 0.61^{\mathrm{d}}$ \\
\hline & 10 & $4.91 \pm 0.52$ & $5.26 \pm 0.21$ & $6.20 \pm 0.63$ & $5.36 \pm 0.18$ & $5.43 \pm 0.61^{\mathrm{c}}$ \\
\hline & 20 & $4.27 \pm 0.62$ & $4.89 \pm 0.25$ & $5.77 \pm 0.50$ & $4.34 \pm 0.12$ & $4.82 \pm 0.72^{\mathrm{b}}$ \\
\hline & 30 & $3.58 \pm 0.23$ & $4.38 \pm 0.42$ & $5.55 \pm 0.46$ & $4.19 \pm 0.56$ & $4.43 \pm 0.83^{\mathrm{a}}$ \\
\hline & Average & $4.58 \pm 0.91^{\mathrm{a}}$ & $5.12 \pm 0.65^{\mathrm{b}}$ & $6.00 \pm 0.56^{c}$ & $4.82 \pm 0.67^{\mathrm{ab}}$ & \\
\hline \multirow[t]{5}{*}{ Yellowness } & 0 & $15.34 \pm 0.12$ & $15.90 \pm 1.24$ & $17.01 \pm 1.48$ & $15.82 \pm 0.98$ & $16.02 \pm 1.13^{\mathrm{a}}$ \\
\hline & 10 & $18.81 \pm 1.13$ & $16.90 \pm 1.51$ & $17.55 \pm 0.60$ & $16.78 \pm 0.88$ & $17.51 \pm 1.25^{\mathrm{b}}$ \\
\hline & 20 & $19.46 \pm 0.17$ & $17.58 \pm 1.01$ & $17.96 \pm 1.97$ & $18.42 \pm 1.23$ & $18.35 \pm 1.31^{\mathrm{bc}}$ \\
\hline & 30 & $19.43 \pm 1.97$ & $18.82 \pm 1.30$ & $18.10 \pm 1.01$ & $18.87 \pm 1.24$ & $18.80 \pm 1.31^{c}$ \\
\hline & Average & $18.26 \pm 2.03$ & $17.30 \pm 1.55$ & $17.65 \pm 1.24$ & $17.47 \pm 1.59$ & \\
\hline \multirow{5}{*}{$\begin{array}{l}\text { Tenderness } \\
(\mathrm{mm} / 50 \mathrm{~g})\end{array}$} & 0 & $11.60 \pm 0.45$ & $11.63 \pm 0.50$ & $11.71 \pm 0.15$ & $11.45 \pm 0.60$ & $11.60 \pm 0.40^{d}$ \\
\hline & 10 & $10.87 \pm 0.22$ & $11.12 \pm 0.50$ & $11.33 \pm 0.45$ & $10.72 \pm 0.34$ & $11.01 \pm 0.41^{c}$ \\
\hline & 20 & $9.94 \pm 0.23$ & $10.21 \pm 0.23$ & $10.41 \pm 0.32$ & $10.01 \pm 0.48$ & $10.14 \pm 0.34^{\mathrm{b}}$ \\
\hline & 30 & $9.49 \pm 0.50$ & $9.57 \pm 0.31$ & $9.68 \pm 0.29$ & $9.42 \pm 0.28$ & $9.54 \pm 0.32^{\mathrm{a}}$ \\
\hline & Average & $10.47 \pm 0.91$ & $10.63 \pm 0.90$ & $10.78 \pm 0.87$ & $10.40 \pm 0.88$ & \\
\hline
\end{tabular}

Means with different superscripts in same column and row are significantly different $(\mathrm{P}<0.05)$.

quality of fat, and non-meat ingredients used in processing. The storage period reduces the tenderness of the nuggets. There was no interaction between the addition of black garlic powder and storage time on the nuggets' tenderness. The reduction in tenderness during storage is due to protein oxidation, which leads to cross-linking and protein polymerization (Lund et al., 2007). Similar findings were reported by Purnamayanti et al. (2020), who stated that the addition of $2 \%$ green tea powder does not affect the lamb sausages' tenderness during 14 days of storage. The addition of $0.03 \%$ rosemary extract and $0.1 \%$ lemon balm did not affect the pork patty's tenderness, but it turned hard for six days of storage (Lara et al., 2011).

\subsection{Chemical properties of nugget}

The addition of black garlic powder did not affect the moisture, protein, and fat content of duck nuggets (Table 4). The results showed that the moisture, protein, and fat content of black garlic powder were 16.94, 15.76, and 2.26\% (Table 2). There is no difference in these components due to the small amount of black garlic powder added to the duck nugget. There was no difference in the moisture and fat content during the storage period, but protein nuggets were decreased. It is due to the decomposition of protein by bacteria (Gill, 1983).

The present finding was also in accordance with the findings of Purnamayanti et al. (2020), who reported that the addition of $2 \%$ green tea powder did not affect the moisture, protein, and fat content of lamb sausage but decreased protein content during 14 days of storage. Lara et al. (2011) showed that the addition of $0.03 \%$ rosemary extract and $0.1 \%$ lemon balm did not affect the pork patty's moisture content for six days of storage. El-Nashi et al. (2015) also reported that the protein content of beef sausage with the addition of $3 \%$ pomegranate powder was decreased during 12 days of storage.

\subsection{Antioxidant activity, peroxide value and total plate count of nugget}

\section{Total phenol}

The total phenol of duck nuggets with black garlic powder and BHT was significantly higher than control during the storage period (Table 5). The increase in total phenol nuggets was correlated with the addition of black garlic powder. Nuggets with $2 \%$ black garlic powder had the highest total phenol, followed by BHT and $1 \%$ black garlic powder. The higher phenol level in duck nuggets was due to black garlic powder having a high phenolic content (Zhang et al., 2016). During the storage periods, the total phenol of all groups was decreased significantly. There was an interaction between the addition of black garlic powder and storage time to total phenol nuggets. During the storage period, fat oxidation has occurred and resulting in decreases in total phenol nugget. Liu et al. (2009) showed that the addition of rosemary or Chinese Mahogany in chicken sausages increased total phenol but decreased during storage. The addition of $0.5 \%$ 
Original Article

Lishianawati; Yusiati; Jamhari

Table 4. Effect of black garlic powder and BHT on chemical properties of duck nugget during storage.

\begin{tabular}{|c|c|c|c|c|c|c|}
\hline \multirow{2}{*}{$\begin{array}{l}\text { Chemical } \\
\text { properties }\end{array}$} & \multirow{2}{*}{ Storage period } & \multicolumn{3}{|c|}{ Black garlic powder (\%) } & \multirow{2}{*}{$\frac{\text { BHT }}{200 \mathrm{ppm}}$} & \multirow[t]{2}{*}{ Average } \\
\hline & & 0 & 1 & 2 & & \\
\hline \multirow[t]{5}{*}{ Moisture (\%) } & 0 & $53.38 \pm 0.88$ & $53.68 \pm 2.11$ & $52.50 \pm 2.98$ & $52.94 \pm 2.66$ & $53.12 \pm 2.02$ \\
\hline & 10 & $54.24 \pm 1.93$ & $53.20 \pm 1.65$ & $51.95 \pm 1.90$ & $52.60 \pm 1.14$ & $53.00 \pm 1.68$ \\
\hline & 20 & $53.13 \pm 1.98$ & $52.72 \pm 1.23$ & $52.24 \pm 0.89$ & $52.62 \pm 1.24$ & $52.70 \pm 1.23$ \\
\hline & 30 & $54.93 \pm 1.10$ & $53.33 \pm 1.64$ & $51.81 \pm 0.96$ & $53.25 \pm 1.29$ & $53.33 \pm 1.58$ \\
\hline & Average & $53.92 \pm 1.52$ & $53.23 \pm 1.48$ & $52.13 \pm 1.63$ & $52.85 \pm 1.47$ & \\
\hline \multirow[t]{5}{*}{ Protein $(\%)$} & 0 & $18.31 \pm 0.45$ & $18.32 \pm 0.37$ & $18.33 \pm 0.44$ & $18.24 \pm 0.95$ & $18.30 \pm 0.51^{\mathrm{b}}$ \\
\hline & 10 & $18.51 \pm 1.04$ & $18.58 \pm 0.46$ & $17.27 \pm 0.64$ & $17.98 \pm 0.79$ & $18.08 \pm 0.85^{b}$ \\
\hline & 20 & $17.44 \pm 0.73$ & $17.31 \pm 0.12$ & $17.54 \pm 0.68$ & $17.33 \pm 0.09$ & $17.41 \pm 0.44^{\mathrm{a}}$ \\
\hline & 30 & $17.14 \pm 0.91$ & $17.05 \pm 0.43$ & $17.28 \pm 0.62$ & $17.90 \pm 0.15$ & $17.34 \pm 0.62^{\mathrm{a}}$ \\
\hline & Average & $17.85 \pm 0.92$ & $17.82 \pm 0.75$ & $17.60 \pm 0.68$ & $17.86 \pm 0.63$ & \\
\hline \multirow[t]{5}{*}{ Fat (\%) } & 0 & $7.51 \pm 0.24$ & $7.46 \pm 0.09$ & $7.44 \pm 0.13$ & $7.49 \pm 0.07$ & $7.47 \pm 0.13$ \\
\hline & 10 & $7.41 \pm 0.31$ & $7.37 \pm 0.19$ & $7.49 \pm 0.12$ & $7.40 \pm 0.18$ & $7.42 \pm 0.19$ \\
\hline & 20 & $7.37 \pm 0.16$ & $7.51 \pm 0.15$ & $7.38 \pm 0.36$ & $7.35 \pm 0.22$ & $7.40 \pm 0.21$ \\
\hline & 30 & $7.31 \pm 0.25$ & $7.36 \pm 0.05$ & $7.50 \pm 0.19$ & $7.41 \pm 0.16$ & $7.40 \pm 0.17$ \\
\hline & Average & $7.40 \pm 0.22$ & $7.42 \pm 0.13$ & $7.45 \pm 0.20$ & $7.41 \pm 0.15$ & \\
\hline
\end{tabular}

Means with different superscripts in same column and row are significantly different $(\mathrm{P}<0.05)$.

Table 5. Effect of black garlic powder and BHT on the total phenol, DPPH inhibition, peroxide value, and TPC of duck nugget during storage.

\begin{tabular}{|c|c|c|c|c|c|c|}
\hline \multirow{2}{*}{$\begin{array}{c}\text { Antioxidant } \\
\text { activity and TPC }\end{array}$} & \multirow{2}{*}{ Storage period } & \multicolumn{3}{|c|}{ Black garlic powder (\%) } & \multirow{2}{*}{$\frac{\text { BHT }}{200 \mathrm{ppm}}$} & \multirow[t]{2}{*}{ Average } \\
\hline & & 0 & 1 & 2 & & \\
\hline \multirow{4}{*}{$\begin{array}{l}\text { Total Phenol } \\
\text { (mg GAE/g) }\end{array}$} & 0 & $5.00 \pm 0.12$ & $5.82 \pm 0.06$ & $8.09 \pm 0.07$ & $7.90 \pm 0.08$ & $6.70 \pm 1.39^{\mathrm{d}}$ \\
\hline & 10 & $4.66 \pm 0.20$ & $5.52 \pm 0.12$ & $7.75 \pm 0.23$ & $7.31 \pm 0.06$ & $6.31 \pm 1.33^{c}$ \\
\hline & 30 & $3.84 \pm 0.22$ & $4.62 \pm 0.09$ & $6.23 \pm 0.23$ & $5.75 \pm 0.11$ & $5.11 \pm 0.99^{\mathrm{a}}$ \\
\hline & Average & $4.48 \pm 0.47^{\mathrm{a}}$ & $5.21 \pm 0.51^{\mathrm{b}}$ & $7.17 \pm 0.83^{d}$ & $6.80 \pm 0.89^{c}$ & \\
\hline \multirow{3}{*}{$\begin{array}{l}\text { DPPH inhibition } \\
\text { (\%) }\end{array}$} & 20 & $23.69 \pm 0.63$ & $28.14 \pm 1.56$ & $38.03 \pm 0.26$ & $36.65 \pm 1.10$ & $31.62 \pm 6.27^{b}$ \\
\hline & 30 & $17.41 \pm 1.28$ & $24.19 \pm 1.19$ & $31.33 \pm 1.41$ & $30.68 \pm 1.04$ & $25.90 \pm 5.99^{\mathrm{a}}$ \\
\hline & Average & $24.53 \pm 5.02^{\mathrm{a}}$ & $30.67 \pm 5.25^{\mathrm{b}}$ & $40.08 \pm 6.53^{d}$ & $38.82 \pm 6.25^{c}$ & \\
\hline \multirow{2}{*}{$\begin{array}{l}\text { Peroxide value } \\
(\mathrm{Meq} / \mathrm{kg})\end{array}$} & 0 & $1.67 \pm 0.30$ & $1.59 \pm 0.13$ & $1.21 \pm 0.07$ & $1.37 \pm 0.04$ & $1.46 \pm 0.24^{\mathrm{a}}$ \\
\hline & 10 & $1.84 \pm 0.25$ & $1.75 \pm 0.21$ & $1.44 \pm 0.17$ & $1.59 \pm 0.18$ & $1.66 \pm 0.24^{\mathrm{b}}$ \\
\hline \multirow[t]{5}{*}{ TPC (log cfu/g) } & 0 & $2.99 \pm 0.03$ & $2.79 \pm 0.11$ & $2.38 \pm 0.04$ & $2.60 \pm 0.03$ & $2.69 \pm 0.24^{\mathrm{a}}$ \\
\hline & 10 & $3.45 \pm 0.01$ & $3.36 \pm 0.04$ & $2.74 \pm 0.16$ & $3.14 \pm 0.04$ & $3.17 \pm 0.30^{b}$ \\
\hline & 20 & $4.32 \pm 0.04$ & $4.14 \pm 0.20$ & $3.23 \pm 0.05$ & $3.78 \pm 0.28$ & $3.87 \pm 0.46^{c}$ \\
\hline & 30 & $5.44 \pm 0.04$ & $4.73 \pm 0.51$ & $4.01 \pm 0.03$ & $4.28 \pm 0.07$ & $4.62 \pm 0.61^{\mathrm{d}}$ \\
\hline & Average & $4.05 \pm 0.97^{\mathrm{d}}$ & $3.76 \pm 0.81^{c}$ & $3.09 \pm 0.64^{\mathrm{a}}$ & $3.45 \pm 0.68^{\mathrm{b}}$ & \\
\hline
\end{tabular}

Means with different superscripts in same column and row are significantly different $(\mathrm{P}<0.05)$.

walnut powder increased the total phenol of pork patties but decreased during 15 days of storage (Boruzi \& Nour, 2019).

\section{DPPH inhibition}

DPPH inhibition of nugget with black garlic powder and $\mathrm{BHT}$ was higher than control during the storage period (Table 5). DPPH inhibition of nuggets added with BHT was higher than $1 \%$ black garlic powder but lower than $2 \%$ black garlic powder. The increase of DPPH inhibition nugget is due to black garlic powder containing secondary metabolite compounds such as phenolic and flavonoids, which have antioxidant properties (Choi et al., 2014; Jang et al., 2017). According to Soobrattee et al. (2005) that an increase in phenolic content can increase antioxidant activity. DPPH inhibition of nuggets decreased as storage time increased. There was no interaction between the black garlic powder and storage time on the DPPH inhibition nugget. $\mathrm{DPPH}$ inhibition decreased due to the total phenol nugget was decreased during storage (Table 4.). Increasing DPPH inhibition of meat and meat product can be done by adding antioxidant compounds. This finding is in accordance with Singh et al. (2014), who reported that the addition of $2 \%$ garlic paste was 
increased DPPH inhibition of chicken meat emulsion but decreased during nine days of storage. Sohaib et al. (2012) also reported that the DPPH inhibition decreased with increasing chicken nugget storage period.

\section{Peroxide value}

Hydroperoxide is the primary product of the oxidative reaction; therefore, the peroxide value measurement indicates the initial stage in lipid oxidation (Min \& Ahn, 2005). The results presented in Table 5. showed that the addition of black garlic powder and BHT reduced the peroxide value of duck nuggets. The decreases of peroxide value were caused by the high antioxidant content of black garlic powder such as polyphenol and flavonoid has a positive correlation with DPPH activity due to hydrogen and electron donation from the hydroxyl group of these compounds (Tomović et al., 2017; Jang et al., 2017). The peroxide value was increased during the storage period. It may be due to the auto-oxidation of meat lipids, bacteriological, and oxidative rancidity (Brewer et al., 1992). Kumar et al. (2015) declared that the addition of $0.3 \%$ sea buckthorn and $0.1 \%$ grape extract on pork patties had lower peroxide values than controls for 21 days of storage. Rahman et al. (2020) also reported that goat nuggets' peroxide value with $0.3 \%$ Moringa leaf extract was lower than the control and BHT for 45 days of storage.

\section{Total plate count}

Total plate count (TPC) showed a significant increasing trend from Day 0 to 30 in all the products. However, the count on the products prepared with the addition of black garlic powder and BHT was significantly lower than control on all storage intervals (Table 5 ). With the addition of $2 \%$ black garlic powder, nuggets had the lowest TPC, followed by BHT and 1\% black garlic powder. The lower total microbial nuggets were caused by the antimicrobial content in black garlic such as phenolic compounds (including phenolic acids and flavonoids) (Papuc et al., 2017b), $\beta$-carbolines alkaloids (Cao et al., 2007), melanoidins (Wang et al., 2011), organic acids and organic sulfur compound (Yin \& Cheng, 2003; Lin et al., 2019). Botas et al. (2019) reported that black garlic has antimicrobial activity against gram-positive and gram-negative bacteria. A similar result was recorded by Bhat et al. (2015) with the addition of $10 \%$ aloe vera has a lower TPC number compared to the controls and increased during 21 days of storage. Kumar et al. (2015) also reported that the use of $0.3 \%$ sea buckthorn and $0.1 \%$ grape in pork patties could prevent microbial growth during 21 days of storage.

\subsection{Sensory evaluation}

Duck nugget with the addition of $2 \%$ black garlic powder was decreased the color, aroma, and overall acceptability but did not affect the taste and texture of the nuggets (Table 6). The addition of BHT did not affect the sensory quality of the nuggets. The decrease in color preference is because black garlic powder has a dark brown color (Ryu \& Kang, 2017). Therefore, the nuggets added with black garlic powder have a darker color compared to controls and BHT. The aroma's decrease is caused by black garlic's distinctive aroma, namely sulfur, sour, sweet,
Table 6. Effect of black garlic powder and BHT on sensory quality of duck nugget.

\begin{tabular}{lccccc}
\hline \multirow{2}{*}{ Sensory attributes } & \multicolumn{3}{c}{ Black garlic powder $(\%)$} & & BHT \\
\cline { 2 - 3 } & 0 & 1 & 2 & & $200 \mathrm{ppm}^{\mathrm{n}}$ \\
\cline { 2 - 3 } Color & $57.25^{\mathrm{c}}$ & $34.95^{\mathrm{b}}$ & $20.42^{\mathrm{a}}$ & & $49.38^{\mathrm{c}}$ \\
Aroma & $48.65^{\mathrm{b}}$ & $37.00^{\mathrm{ab}}$ & $27.75^{\mathrm{a}}$ & & $48.60^{\mathrm{b}}$ \\
Taste & 48.60 & 39.45 & 32.65 & & 41.30 \\
Texture & 48.00 & 37.20 & 35.45 & & 41.35 \\
Overall acceptability & $50.05^{\mathrm{b}}$ & $38.78^{\mathrm{ab}}$ & $30.68^{\mathrm{a}}$ & & $42.50^{\mathrm{ab}}$ \\
\hline
\end{tabular}

Means with different superscripts in same row are significantly different $(\mathrm{P}<0.05)$.

fresh, spicy, gasoline, and roasted odors (Yang et al., 2019). The decrease in duck nuggets' acceptance was based on all sensory attributes the nuggets with the addition of black garlic powder had a lower score than the control and BHT.

Similar reports were noticed by Bhat et al. (2015) in chicken nuggets, which added 15\% aloe vera decreased the color and overall acceptability. The addition of $2 \%$ broccoli powder extract did not affect the goat nuggets' taste and texture (Banerjee et al., 2012). The addition of $2 \%$ aged garlic powder did not affect the pork patty's texture (Kim et al., 2019). Sujarwanta et al. (2019) also reported that the addition of $2 \%$ of Curcuma flour decreased the aroma of chicken nuggets.

\section{Conclusion}

The addition of $2 \%$ black garlic powder had better total phenol, DPPH inhibition, peroxide value, and TPC quality during storage but decreased the spent duck meat nuggets' sensory quality. The addition of $1 \%$ black garlic power has a better physical, chemical, total phenol, DPPH inhibition, peroxide value, and TPC quality than the control but lower than BHT during storage, and the sensory quality is not different. The addition of $1 \%$ black garlic powder was recommended to increase the spent duck meat nugget quality during storage without decrease the sensory quality of nuggets.

\section{References}

Ahmed, M., Pickova, J., Ahmad, T., Liaquat, M., Farid, A., \& Jahangir, M. (2016). Oxidation of lipids in foods. Sarhad Journal of Agriculture, 32(3), 230-238. http://dx.doi.org/10.17582/journal.sja/2016.32.3.230.238.

Ali, S., Kang, G., Yang, H., Jeong, J., Hwang, Y., Park, G., \& Joo, S. (2007). A comparison of meat characteristics between duck and chicken breast. Asian-Australasian Journal of Animal Sciences, 20(6), 10021006. http://dx.doi.org/10.5713/ajas.2007.1002.

Altuntas, S., \& Korukluoglu, M. (2019). Growth and effect of garlic (Allium sativum) on selected beneficial bacteria. Food Science and Technology, 39(4), 897-904. http://dx.doi.org/10.1590/fst.10618.

Amaral, A. B., Silva, M. V., \& Lannes, S. C. D. S. (2018). Lipid oxidation in meat: mechanisms and protective factors: a review. Food Science and Technology, 38(1, Suppl. 1), 1-15. http://dx.doi.org/10.1590/fst.32518.

Arslaner, A. (2020). The effects of adding garlic (Allium sativum L.) on the volatile composition and quality properties of yogurt. Food Science and Technology, 40(Suppl. 2), 582-591. http://dx.doi. org/10.1590/fst.31019.

Association of Official Analytical Chemists - AOAC (2005). Official Methods of Analysis (20th ed). Washigton DC: Association of Official Analytical Chemists. 
Badan Standardisasi Nasional - BSN. (2008). Standar Nasional Indonesia (SNI) 2897:2008: metode pengujian cemaran mikroba dalam daging, telur dan susu, serta hasil olahannya. Jakarta: BSN.

Banerjee, R., Verma, A. K., Das, A. K., Rajkumar, V., Shewalkar, A. A., \& Narkhede, H. P. (2012). Antioxidant effects of broccoli powder extract in goat meat nuggets. Meat Science, 91(2), 179-184. http:// dx.doi.org/10.1016/j.meatsci.2012.01.016. PMid:22330944.

Berliana, N., Nurhayati, N., \& Nelwida, N. (2018). Substitusi tepung Bawang Putih (Allium sativum) dengan Bawang Hitam (Black Garlic) dalam ransum terhadap umur bertelur dan bobot telur pertama Puyuh (Coturnix - coturnix japonica). Jurnal Agripet, 18(2), 95-102. http://dx.doi.org/10.17969/agripet.v18i2.12779.

Bhat, Z. F., Kumar, S., \& Kumar, P. (2015). Effect of aloe vera on the lipid stability and storage quality of chicken nuggets. Nutrition \& Food Science, 45(1), 54-67. http://dx.doi.org/10.1108/NFS-04-2014-0034.

Boruzi, A. I., \& Nour, V. (2019). Walnut (Juglans regia L.) leaf powder as a natural antioxidant in cooked pork patties. CYTA: Journal of Food, 17(1), 431-438. http://dx.doi.org/10.1080/19476337.2019.1596984.

Botas, J., Fernandes, Â., Barros, L., Alves, M. J., Carvalho, A. M., \& Ferreira, I. C. F. R. (2019). A comparative study of black and white Allium sativum L.: nutritional composition and bioactive properties. Molecules, 24(11), 2194-2205. http://dx.doi.org/10.3390/ molecules24112194. PMid:31212722.

Brewer, M. S., Ikins, W. G., \& Harbers, C. A. Z. (1992). TBA values, sensory characteristics, and volatiles in ground pork during longterm frozen storage: effects of packaging. Journal of Food Science, 57(3), 558-564. http://dx.doi.org/10.1111/j.1365-2621.1992.tb08042.x.

Cao, R., Peng, W., Wang, Z., \& Xu, A. (2007). $\beta$-Carboline alkaloids: biochemical and pharmacological functions. Current Medicinal Chemistry, 14(4), 479-500. http://dx.doi.org/10.2174/092986707779940998. PMid:17305548.

Cayré, M. E., Vignolo, G., \& Garro, O. (2003). Modeling lactic acid bacteria growth in vacuum-packaged cooked meat emulsions stored at three temperatures. Food Microbiology, 20(5), 561-566. http:// dx.doi.org/10.1016/S0740-0020(02)00154-5.

Choi, D. J., Lee, S. J., Kang, M. J., Cho, H. S., Sung, N. J., \& Shin, J. H. (2008). Physicochemical characteristics of black garlic (Allium sativum L. ). Journal of the Korean Society of Food Science and Nutrition, 37(4), 465-471. http://dx.doi.org/10.3746/jkfn.2008.37.4.465.

Choi, I. S., Cha, H. S., \& Lee, Y. S. (2014). Physicochemical and antioxidant properties of black garlic. Molecules, 19(10), 16811-16823. http:// dx.doi.org/10.3390/molecules191016811. PMid:25335109.

Costa, J. N., Brito, S. A., Leal, A. R., Rodrigues, D. da C., Nascimento, L. G. L., Figueiredo, R. W., Mata, P., \& Sousa, P. H. M. (2020). Sensory characteristics of structured guava (Psidium guajava): comparison of optimized descriptive profile, cata and sensory acceptance methods. Food Science and Technology, 40(Suppl. 2), 496-502. http://dx.doi. org/10.1590/fst.25819.

Damayanti, A. P. (2006). Kandungan protein, lemak daging dan kulit itik, entog dan mandalung umur 8 minggu. Jurnal Agroland, 13(3), 313-317.

Domínguez, R., Pateiro, M., Gagaoua, M., Barba, F. J., Zhang, W., \& Lorenzo, J. M. (2019). A comprehensive review on lipid oxidation in meat and meat products. Antioxidants, 8(10), 1-31. http://dx.doi. org/10.3390/antiox8100429. PMid:31557858.

El-Nashi, H. B., Abdel Fattah, A. F. A. K., Abdel Rahman, N. R., \& Abd ElRazik, M. M. (2015). Quality characteristics of beef sausage containing pomegranate peels during refrigerated storage. Annals of Agricultural Science, 60(2), 403-412. http://dx.doi.org/10.1016/j.aoas.2015.10.002.

Gahruie, H. H., Hosseini, S. M. H., Taghavifard, M. H., Eskandari, M. H., Golmakani, M. T., \& Shad, E. (2017). Lipid oxidation, color changes, and microbiological quality of frozen beef burgers incorporated with shirazi thyme, cinnamon, and rosemary extracts. Journal of Food Quality, 2017, 1-9. http://dx.doi.org/10.1155/2017/6350156.

Gill, C. O. (1983). Meat spoilage and evaluation of the potential storage life of fresh meat. Journal of Food Protection, 46(5), 444-452. http:// dx.doi.org/10.4315/0362-028X-46.5.444. PMid:30913652.

Hinnergardt, L. C., \& Tuomy, J. M. (1970). A penetrometer test to measure meat tenderness. Journal of Food Science, 35(3), 312-315. http://dx.doi.org/10.1111/j.1365-2621.1970.tb12172.x.

Jang, H., Lee, H., Yoon, D., Ji, D., Kim, J.-H., \& Lee, C.-H. (2017). Antioxidant and antimicrobial activities of fresh garlic and aged garlic by-products extracted with different solvents. Food Science and Biotechnology, 27(1), 219-225. http://dx.doi.org/10.1007/s10068017-0246-4. PMid:30263743.

Kim, J. H., Jang, H. J., \& Lee, C. H. (2019). Effect of aged garlic powder on physicochemical characteristics, texture profiles, and oxidative stability of ready-to-eat pork patties. Asian-Australasian Journal of Animal Sciences, 32(7), 1027-1035. http://dx.doi.org/10.5713/ ajas.18.0689. PMid:30744360.

Kimura, S., Tung, Y., Pan, M., Su, N., Lai, Y., \& Cheng, K. (2017). Black garlic: a critical review of its production, bioactivity, and application. Journal of Food and Drug Analysis, 25(1), 62-70. PMid:28911544.

Konica Minolta. (2013). Chroma meter CR-400/410 instruction manual. Solna: Konica Minolta, Inc.

Korkeala, H., Mäki-Petäys, O., Alanko, T., \& Sorvettula, O. (1986). Determination of $\mathrm{pH}$ in meat. Meat Science, 18(2), 121-132. http:// dx.doi.org/10.1016/0309-1740(86)90088-4. PMid:22055566.

Kumar, V., Chatli, M. K., Wagh, R. V., Mehta, N., \& Kumar, P. (2015). Effect of the combination of natural antioxidants and packaging methods on quality of pork patties during storage. Journal of Food Science and Technology, 52(10), 6230-6241. http://dx.doi.org/10.1007/ s13197-015-1734-2. PMid:26396369.

Lara, M. S., Gutierrez, J. I., Timón, M., \& Andrés, A. I. (2011). Evaluation of two natural extracts (Rosmarinus officinalis L. and Melissa officinalis L.) as antioxidants in cooked pork patties packed in MAP. Meat Science, 88(3), 481-488. http://dx.doi.org/10.1016/j. meatsci.2011.01.030. PMid:21345605.

Lee, J., Seong, Y., Jeong, B., Yoon, S., Lee, I., \& Jeong, Y. (2009). Quality characteristics of sponge cake with black garlic powder added. Journal of the Korean Society of Food Science and Nutrition, 38(9), 1222-1228. http://dx.doi.org/10.3746/jkfn.2009.38.9.1222.

Lin, S. C., Chagnaadorj, A., Bayarsengee, U., Leung, T. K., \& Cheng, C. W. (2019). The compound, diallyl disulfide, enriched in garlic, prevents the progressiodoxorubicin-induced nephropathy. Food Science and Technology, 39(4), 1040-1046. http://dx.doi.org/10.1590/fst.15418.

Liu, D. C., Tsau, R. T., Lin, Y. C., Jan, S. S., \& Tan, F. J. (2009). Effect of various levels of rosemary or Chinese mahogany on the quality of fresh chicken sausage during refrigerated storage. Food Chemistry, 117(1), 106-113. http://dx.doi.org/10.1016/j.foodchem.2009.03.083.

Lu, X., Li, N., Qiao, X., Qiu, Z., \& Liu, P. (2017). Composition analysis and antioxidant properties of black garlic extract. Journal of Food and Drug Analysis, 25(2), 340-349. PMid:28911676.

Lukman, I., Huda, N., \& Ismail, N. (2009). Physicochemical and sensory properties of commercial chicken nuggets. Asian Journal of Food and Agro-Industry, 2(02), 171-180.

Lund, M. N., Lametsch, R., Hviid, M. S., Jensen, O. N., \& Skibsted, L. H. (2007). High-oxygen packaging atmosphere influences protein oxidation and tenderness of porcine longissimus dorsi during chill storage. Meat Science, 77(3), 295-303. http://dx.doi.org/10.1016/j. meatsci.2007.03.016. PMid:22061781. 
Matitaputty, P. R., \& Suryana. (2010). Karakteristik daging itik dan permasalahan serta upaya pencegahan off-flavor akibat oksidasi lipida. Wartazoa, 20(3), 130-138.

Min, B., \& Ahn, D. U. (2005). Mechanism of lipid peroxidation in meat and meat products a review. Food Science and Biotechnology, 14(1), 152-163.

Nascimento, R. Q., Tavares, P. P. L. G., Meireles, S., Anjos, E. A., Andrade, R. B., Machado, B. A. S., Souza, A. L. C., \& Mamede, M. E. O. (2020). Study on the sensory acceptance and check all that apply of mixed juices in distinct Brazilian regions. Food Science and Technology, 40(Suppl. 2), 708-717. http://dx.doi.org/10.1590/fst.37619.

Papuc, C., Goran, G. V., Predescu, C. N., \& Nicorescu, V. (2017a). Mechanisms of oxidative processes in meat and toxicity induced by postprandial degradation products: a review. Comprehensive Reviews in Food Science and Food Safety, 16(1), 96-123. http://dx.doi. org/10.1111/1541-4337.12241. PMid:33371549.

Papuc, C., Goran, G. V., Predescu, C. N., Nicorescu, V., \& Stefan, G. (2017b). Plant polyphenols as antioxidant and antibacterial agents for shelf-life extension of meat and meat products: classification, structures, sources, and action mechanisms. Comprehensive Reviews in Food Science and Food Safety, 16(6), 1243-1268. http://dx.doi. org/10.1111/1541-4337.12298. PMid:33371586.

Purnamayanti, L., Jamhari, J., Hanim, C., \& Irawan, A. (2020). Physicochemical properties, oxidative stability, and sensory quality of lamb sausage added with green tea leaves (Camelia sinensis) powder. Tropical Animal Science Journal, 43(1), 57-63. http://dx.doi. org/10.5398/tasj.2020.43.1.57.

Rahman, M. H., Alam, M. S., Monir, M. M., \& Rahman, S. M. E. (2020). Effect of Moringa oleifera leaf extract and synthetic antioxidant on quality and shelf-life of goat meat nuggets at frozen storage. International Journal of Food Research, 7(4), 34-45.

Ryu, J. H., \& Kang, D. (2017). Physicochemical properties, biological activity, health benefits, and general limitations of aged black garlic: a review. Molecules 22(6), 919-933. http://dx.doi.org/10.3390/ molecules22060919. PMid:28587168.

Sallam, K. I., \& Samejima, K. (2004). Microbiological and chemical quality of ground beef treated with sodium lactate and sodium chloride during refrigerated storage. Lebensmittel-Wissenschaft + Technologie, 37(8), 865-871. http://dx.doi.org/10.1016/j.lwt.2004.04.003. PMid:17330155.

Sánchez-Escalante, A., Djenane, D., Torrescano, G., Beltrán, J. A., \& Roncalés, P. (2001). The effects of ascorbic acid, taurine, carnosine and rosemary powder on colour and lipid stability of beef patties packaged in modified atmosphere. Meat Science, 58(4), 421-429. http://dx.doi.org/10.1016/S0309-1740(01)00045-6. PMid:22062434.

Santhi, D., Kalaikannan, A., \& Sureshkumar, S. (2017). Factors influencing meat emulsion properties and product texture: a review. Critical Reviews in Food Science and Nutrition, 57(10), 2021-2027. http:// dx.doi.org/10.1080/10408398.2013.858027. PMid:25836950.

Schuch, A. F., Silva, A. C., Kalschne, D. L., Silva-Buzanello, R. A., Corso, M. P., \& Canan, C. (2019). Chicken nuggets packaging attributes impact on consumer purchase intention. Food Science and Technology, 39(Suppl. 1), 152-158. http://dx.doi.org/10.1590/fst.41317.

Shantha, N. C., \& Decker, E. A. (1994). Rapid, sensitive, iron-based spechtrophotometric method for determination of peroxide values of food lipids. Journal of AOAC International, 77(2), 421-424. http:// dx.doi.org/10.1093/jaoac/77.2.421. PMid:8199478.

Shimamura, T., Sumikura, Y., Yamazaki, T., Tada, A., Kashiwagi, T., Ishikawa, H., Matsui, T., Sugimoto, N., Akiyama, H., \& Ukeda, H. (2014). Applicability of the DPPH assay for evaluating the antioxidant capacity of food additives-inter-laboratory evaluation study. Analytical Sciences, 30(7), 717-721. http://dx.doi.org/10.2116/ analsci.30.717. PMid:25007929.

Shin, D. M., Kim, D. H., Yune, J. H., Kwon, H. C., Kim, H. J., Seo, H. G., \& Han, S. G. (2019). Oxidative stability and quality characteristics of duck, chicken, swine and bovine skin fats extracted by pressurized hot water extraction. Food Science of Animal Resources, 39(3), 446458. http://dx.doi.org/10.5851/kosfa.2019.e41. PMid:31304473.

Shin, J.-H., Kang, M.-J., Kim, R.-J., \& Sung, N.-J. (2011). The quality characteristics of sausage with added black garlic extracts. Korean Journal Food Cookery Science, 27(6), 702-711. http://dx.doi. org/10.9724/kfcs.2011.27.6.701.

Singh, P., Sahoo, J., Chatli, M. K., \& Biswas, A. K. (2014). Shelf life evaluation of raw chicken meat emulsion incorporated with clove powder, ginger and garlic paste as natural preservatives at refrigerated storage $\left(4 \pm 1^{\circ} \mathrm{C}\right)$. International Food Research Journal, 21(4), 1363-1373.

Singleton, V. L., Orthofer, R., \& Lamuela-Raventós, R. M. (1999). Analysis of total phenols and other oxidation substrates and antioxidants by means of folin-ciocalteu reagent. Methods in Enzymology, 299, 152178. http://dx.doi.org/10.1016/S0076-6879(99)99017-1.

Sohaib, M., Anjum, F. M., Khan, M. I., Arshad, M. S., \& Shahid, M. (2012). Enhancement of lipid stability of broiler breast meat and meat products fed on alpha lipoic acid and alpha tocopherol acetate supplemented feed. Lipids in Health and Disease, 11(1), 57. http:// dx.doi.org/10.1186/1476-511X-11-57. PMid:22640892.

Soobrattee, M. A., Neergheen, V. S., Luximon-Ramma, A., Aruoma, O. I., \& Bahorun, T. (2005). Phenolics as potential antioxidant therapeutic agents: mechanism and actions. Mutation Research. Fundamental and Molecular Mechanisms of Mutagenesis, 579(1-2), 200-213. http://dx.doi.org/10.1016/j.mrfmmm.2005.03.023. PMid:16126236.

Sujarwanta, R. O., Jamhari, Suryanto, E., Yuliatmo, R., \& Prayitno, A. H. (2019). Physicochemical and sensory characteristics of chicken nugget with curcuma (Curcuma zanthorrhiza) flour fortification. IOP Conference Series: Earth and Environmental Science, 387(1), 012091. http://dx.doi.org/10.1088/1755-1315/387/1/012091.

Tomović, V., Jokanović, M., Šojić, B., Škaljac, S., \& Ivić, M. (2017). Plants as natural antioxidants for meat products. IOP Conference Series: Earth and Environmental Science, 85(1), 012030. http://dx.doi. org/10.1088/1755-1315/85/1/012030.

Wang, J. P., Yoo, J. S., Jang, H. D., Lee, J. H., Cho, J. H., \& Kim, I. H. (2011). Effect of dietary fermented garlic by Weissella koreensis powder on growth performance, blood characteristics, and immune response of growing pigs challenged with Escherichia coli lipopolysaccharide. Journal of Animal Science, 89(7), 2123-2131. http://dx.doi.org/10.2527/ jas.2010-3186. PMid:21317348.

Wang, W., \& Sun, Y. (2017). In vitro and in vivo antioxidant activities of polyphenol extracted from black garlic. Food Science and Technology, 37(4), 681-685. http://dx.doi.org/10.1590/1678-457x.30816.

Yang, P., Song, H., Wang, L., \& Jing, H. (2019). Characterization of key aroma-active compounds in black garlic by sensory-directed flavor analysis. Journal of Agricultural and Food Chemistry, 67(28), 79267934. http://dx.doi.org/10.1021/acs.jafc.9b03269. PMid:31250635.

Yin, M. C., \& Cheng, W. S. (2003). Antioxidant and antimicrobial effects of four garlic-derived organosulfur compounds in ground beef. Meat Science, 63(1), 23-28. http://dx.doi.org/10.1016/S03091740(02)00047-5. PMid:22061980.

Zhang, X., Li, N., Lu, X., Liu, P., \& Qiao, X. (2016). Effects of temperature on the quality of black garlic. Journal of the Science of Food and Agriculture, 96(7), 2366-2372. http://dx.doi.org/10.1002/jsfa.7351. PMid:26212875. 